\title{
The preparation of virus-infected cells for use in immunofluorescence techniques
}

\author{
GEORGE SANDER, J. P. V. HAYHOE, AND ANNE McSHANE \\ From the Division of Immunological Products Control, National Institute for Medical Research, \\ (Hampstead Laboratories), London
}

SYNOPSIS This paper describes the preparation of virus-infected cells for the detection of serum antibodies by the use of immunofluorescence techniques. The variations in virus growth in cells in relation to the length of incubation of cell monolayers and polio virus using two different fluorescein isothiocynate conjugates are discussed. It is shown that there is a critical time after virus infection when a definite positive immunofluorescent reaction is given. Furthermore, a method is described enabling the clinical pathologist to prepare infected cells with the use of an automatic tube inoculator at any time during 24 hours.

There is a need for a ready supply of cells infected with specific viruses in order to detect antibody in clinical specimens. Such cells, fixed and stored, would be useful in the rapid detection of rubella antibody in the blood of a pregnant woman who had recently been in contact with German measles. Sander (1969) has already described the method of fixing cells grown on coverslips so that they may be stored for long periods at room temperature. It is important, however, to use preparations at a time when the virus may be detected most easily. Thus the critical point at which the number of virus particles is at a maximum before too much damage is done to the cell must be determined for each system of virus and cell.

Darnell, Levintlow, Thoren, and Hooper (1961) and Mayor (1961) have already shown, using other systems, that there is no linear relationship between the time after infection and ability to detect virus.

The purpose of this report is to investigate the optimal time for staining the cells and todescribe an automatic tube inoculation apparatus in order to arrange that the critical time of harvest is convenient for the clinical pathologist.

Received for publication 19 January 1970.

\section{Materials and Methods}

PREPARATION OF INFECTED CELLS

Standard test tubes each containing a $13 \mathrm{~mm}$ diameter round coverslip were sterilized at

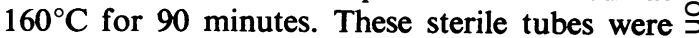
then seeded with $1.5 \mathrm{ml}$ of a suspension of monkey

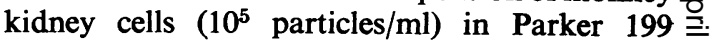
medium containing $5 \%$ calf serum and incubated $N$ so that the cover glass was horizontal. The cells grew to a confluent sheet in about four days $\stackrel{\sim}{N}$ at which time the medium was changed and inoculated with $10^{5}$ particles of poliomyelitis virus. After further incubation at $37^{\circ} \mathrm{C}$ the cells $\mathscr{C}$ on each of two cover glasses were fixed at a time interval each hour from one to 24 hours after virus infection.

\section{FIXATION OF CELLS}

The medium in each tube was discarded and acetone at $4^{\circ} \mathrm{C}$ used as a rinse before replacing 8 with $5 \mathrm{ml}$ of fresh cold acetone. The tubes were then placed in a bath of industrial spirit and solid $\mathrm{CO}_{2}\left(-60^{\circ} \mathrm{C}\right)$ for 30 minutes. After fixation the coverslips were removed and 

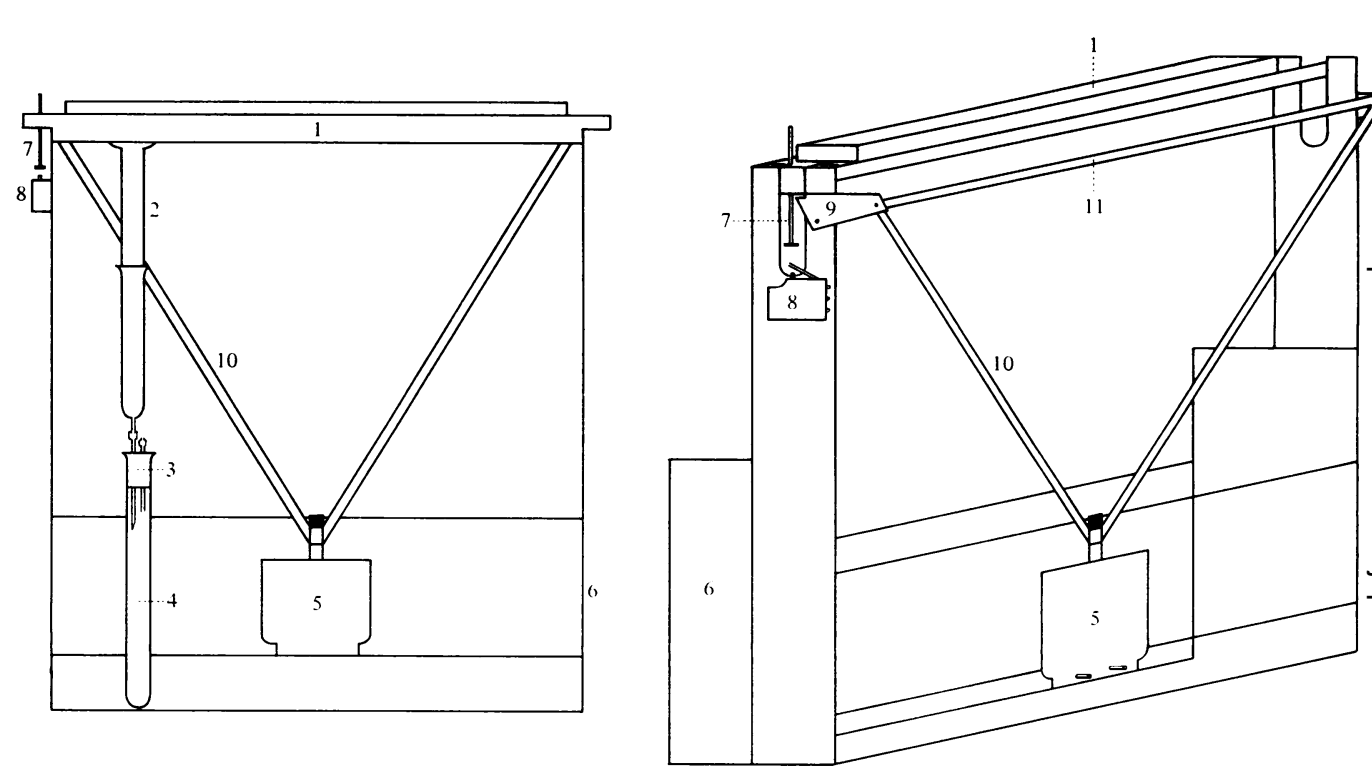

Fig. 1a Apparatus for tube inoculation (front) 1 Weighted bar (recessed for plunger tops)

$21 \mathrm{ml}$ syringe

3 Rubber bung with needle for injection and plugged air vent

4 Test tube

5 Solenoid

6 Tissue culture rack

Fig. 1b Apparatus for tube inoculation (back) 7 Switch activating rod (sprung)

8 Micro switch

9 Bar release trigger

10 Release arms

11 Distance bar

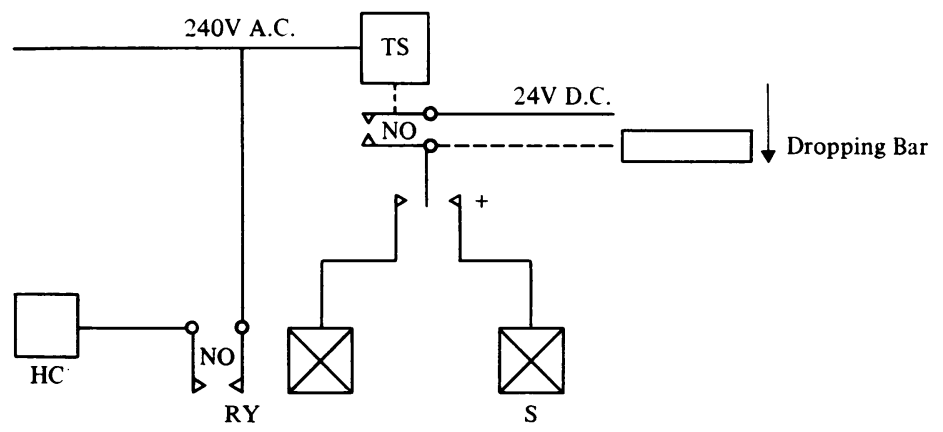

Fig. 1c Electrical circuit

TS Time switch

S Solenoid

RY Relay $24 V D C$

HC Hour counter

+ See text (micro switch no. 8)

\begin{tabular}{|c|c|c|c|c|c|c|c|c|c|c|c|c|}
\hline \multirow[t]{2}{*}{ Conjugate } & \multirow{2}{*}{$\begin{array}{l}\text { Polio } \\
\text { Virus } \\
\text { Type }\end{array}$} & \multicolumn{11}{|c|}{ Time after Virus Infection (in Hours) } \\
\hline & & 1 & 2 & 3 & 4 & 5 & 6 & 7 & 8 & 9 & 10 & 11 \\
\hline $\mathbf{A}$ & $\begin{array}{l}\text { I } \\
\text { II } \\
\text { III }\end{array}$ & $\frac{-}{+}$ & $\begin{array}{l}(+)^{2} \\
(+)\end{array}$ & $\begin{array}{l}+ \\
+ \\
+\end{array}$ & $\begin{array}{l}+ \\
+ \\
+\end{array}$ & $\begin{array}{l}+ \\
+ \\
+\end{array}$ & $\begin{array}{l}(+) \\
+(+) \\
(+)\end{array}$ & $\begin{array}{l}(+) \\
(+) \\
+\end{array}$ & $\begin{array}{l}(+) \\
+ \\
+\end{array}$ & $\begin{array}{l}++ \\
++ \\
(+)\end{array}$ & $\begin{array}{l}+(+) \\
++ \\
+\end{array}$ & $\begin{array}{l}++ \\
++ \\
(+)\end{array}$ \\
\hline $\mathbf{B}$ & $\begin{array}{l}\text { I } \\
\text { II } \\
\text { III }\end{array}$ & $\begin{array}{l}\overline{-} \\
\overline{(+\dot{+})}\end{array}$ & $\begin{array}{l} \pm \\
- \\
-\end{array}$ & $\begin{array}{l}+ \\
\frac{+}{(+)}\end{array}$ & $\begin{array}{l}+(+) \\
(+)\end{array}$ & $\begin{array}{l}+(+) \\
+ \\
(+)\end{array}$ & $\begin{array}{l}+(+) \\
+(+) \\
(+)\end{array}$ & $\begin{array}{l}(+) \\
+ \\
(+)\end{array}$ & $\begin{array}{l}+(+) \\
+ \\
+\end{array}$ & $\begin{array}{l}+ \\
+++ \\
+(+)\end{array}$ & $\begin{array}{l}+ \\
++(+) \\
++\end{array}$ & $\begin{array}{l}+ \\
++(+) \\
++\end{array}$ \\
\hline
\end{tabular}


dried in the air and stored at room temperature. These cells are quite stable and may be stored indefinitely.

\section{STAINING AND MOUNTING CELLS}

Each monolayer of cells was stained by conjugate by the sandwich technique (Sander, 1969), using type-specific antiserum. Control cells were taken and fixed each time infected cells were sampled in order that the immunofluorescence given by conjugate alone on infected and normal cells, as well as the immunofluorescence given by non-infected cells, with the complete staining technique could be checked.

After staining and dehydration the coverslips were mounted in freshly made DPX prepared by dissolving $18.75 \mathrm{ml}$ of tri-p-tolyl phosphate and $25 \mathrm{~g}$ of distrene $80 \mathrm{in} 100 \mathrm{ml}$ of xylene (Baker, 1966).

\section{ILLUMINATION SYSTEM}

A monocular microscope was used fitted with HBO 200 mercury vapour lamp in a Zeiss housing, $3 \mathrm{~mm} \mathrm{Ug} 1$ filter Schott Jena, surface aluminized mirror, Zeiss cardioid dark-field condenser (water immersed), and a $5 \mathrm{~mm}$ GG 13 barrier filter Schott Jena (colourless).

\section{APPARATUS FOR TUBE INOCULATION}

A standard tissue culture rack (6) was fitted with two uprights, each $330 \times 40 \mathrm{~mm}$, which were grooved at the top to a depth of $65 \mathrm{~mm}$ (Figs. 1a and $1 \mathrm{~b}$ ). To the centre back of the rack a $24 \mathrm{~V}$ DC solenoid (5) was fitted and this was also attached to two release arms (10) which in turn were connected to a bar release trigger (9).

The electrical circuit (Fig. 1c) consisted of a time switch, TS, having open contacts in the normal position, a microswitch (8) with the NO contact to the solenoid (5) and a $24 \mathrm{~V}$ DC relay, the NO contact of which was connected to the hour counter HC 240 V AC.

In operation the test tube (4) containing coverslip and medium was placed in the back row of the rack; the syringe assembly, filled with virus suspension and kept at $37^{\circ} \mathrm{C}$ to prevent leakage, was inserted in the test tube and the plunger raised to fit into the recess of the weighted bar (1) which rested on the bar release trigger (9) $\overline{\bar{J}}$

After a preset time, the time switch activated the solenoid which released the trigger to allow the bar to drop, simultaneously injecting the virus suspension into the test tube. At the enc of the travel the dropping bar contacted the microswitch via rod (7) which deactivated the solenoid and activated the hour counter givinge the time of incubation with virus. Although the apparatus was constructed for eight test tubes? it could be made larger, bearing in mind the needes to fit the apparatus into an incubator.

\section{Results}

The results of intensity of illumination of cellst shown in arbitrary degrees, indicated by - to +++ , with $(+)$ indicating an intermediate value, for each of two conjugates, $A$ and $B$, are shown in the Table. These results are re- $\frac{}{3}$ producible and have remained constant for four years.

It is clear that the optimum time after virus $\vec{\theta}$ infection for fixing the cells $(++$ or greater). differs for each of the three types of poliomyelitis virus. It is also of interest to note that this time is dependent also upon the conjugate used. With type III virus, for example, good。 staining can be seen in three hours with conjugate $\stackrel{\mathbb{Q}}{\stackrel{2}{ }}$ A whereas virus growth for 10 hours is required $\overrightarrow{\vec{O}}$ with conjugate $B$.

\section{Discussion}

It is well recognized that the replication of viruses

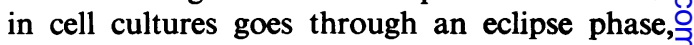
during which virus cannot be detected, to a phase of complete virus production. If this relationship held when virus was detected by immunofluorescent techniques then it would be rational to leave the cell cultures for a given $N$ time after virus infection and thereafter virus would always be detectable. This indeed would

Time after Virus Infection (in Hours)

\begin{tabular}{|c|c|c|c|c|c|c|c|c|c|c|c|c|}
\hline 12 & 13 & 14 & 15 & 16 & 17 & 18 & 19 & 20 & 21 & 22 & 23 & 24 \\
\hline $\begin{array}{l}++ \\
++(+) \\
+\end{array}$ & $\begin{array}{l}+(+) \\
++\end{array}$ & $\begin{array}{l}+(+) \\
(+) \\
++(+)\end{array}$ & $\begin{array}{l}(+) \\
(+) \\
+++\end{array}$ & $\begin{array}{l}- \\
+ \\
+\end{array}$ & $\begin{array}{l}- \\
(+) \\
+\end{array}$ & $\begin{array}{l}+ \\
+\end{array}$ & $\begin{array}{l}+ \\
+ \\
+\end{array}$ & $\begin{array}{l}(+) \\
+(+) \\
++\end{array}$ & $\begin{array}{l}+ \\
++) \\
+++\end{array}$ & $\begin{array}{l}+ \\
+ \\
++(+)\end{array}$ & $\begin{array}{l}(+) \\
+(+) \\
+(+)\end{array}$ & $\begin{array}{l}(+) \\
+(+) \\
++\end{array}$ \\
\hline $\begin{array}{l}++ \\
+++ \\
++\end{array}$ & $\begin{array}{l}+++ \\
+++ \\
-\end{array}$ & $\begin{array}{l}+++ \\
++ \\
+\end{array}$ & $\begin{array}{l}++ \\
++(+) \\
+\end{array}$ & $\begin{array}{l}+ \\
++ \\
+(+)\end{array}$ & $\begin{array}{l}+ \\
+(+) \\
+(+)\end{array}$ & $\begin{array}{l}- \\
+ \\
+(+)\end{array}$ & $\begin{array}{l}- \\
(+) \\
(+)\end{array}$ & $\begin{array}{l}- \\
(+) \\
+(+)\end{array}$ & $\begin{array}{l}- \\
+ \\
+\end{array}$ & $\begin{array}{l}(+) \\
+(+)\end{array}$ & $\begin{array}{l}++ \\
(+) \\
+(+)\end{array}$ & $\begin{array}{l}+++ \\
(+) \\
+(+)\end{array}$ \\
\hline
\end{tabular}


be satisfactory if it were not critical to make an early diagnosis of virus infection or of the presence of antibody. It is clear from these data, however, that there is a critical time, after virus infection, at which virus is present in sufficient quantity to give a definite positive reaction easily distinguishable from the autoimmune fluorescence seen to some degree with all cells and all conjugates.

The differences in the time at which virus may be detected by different conjugates are surprising but it must be emphasized that these results are reproducible, and they underline the need to investigate the optimum time for each virus, each cell substrate, and each conjugate. When the optimal time for each system has been established, however, the results are reproducible-

These data will enable the clinical pathologis:

to prepare infected cells using the automatif tube inoculator at any time during the 24-hout daily period so that the cells will be at the opt产 mum time for virus detection at any convenient moment to him.

References

Baker, J. R. (1966). Cytological Technique, 5th ed., p. 13 Methuen, London.

Darnell, J. E., Jr., Levintow, L., Thoren, M. M., and Hooper, J. \&్ ֶ, (1961). The time course of synthesis of poliovirus RNA. Virology, 13, 271-279.

Mayor, H. D. (1961). Cytochemical and fluorescent antibody studies on the growth of poliovirus in tissue culturg Tex. Rep. Biol. Med., 19, 106-122. Sander, G. (1969). Storage of virus-infected tissue culture sut
strates for the detection of serum antibodies by immuri fluor escence. J. clin. Path., 22, 737. 